IJMS 16 (1), 185-212 (2009)

\title{
EFFECTS OF FISCAL POLICY AND INSTITUTIONS ON THE ECONOMIC GROWTH OF ASIAN ECONOMIES: EVIDENCE FROM DYNAMIC PANEL DATA ANALYSIS
}

\author{
HUSSIN ABDULLAH \\ College of Arts and Sciences \\ Universiti Utara Malaysia \\ MUZAFAR SHAH HABIBULLAH \\ AHMAD ZUBAIDI BAHARUMSHAH \\ Faculty of Economics and Management \\ Universiti Putra Malaysia
}

\begin{abstract}
This paper investigates the effects of fiscal policy and institutions on the economic growth of Asian economies through the application of the GMM-SYS approach to dynamic panel estimator as a preference analysis. It examines two different channels through which fiscal policy can affect long-run economic growth in Asia. The first channel is when aggregate government expenditure, aggregate of other fiscal variables, and institution affect the real per capita GDP, and the second channel is to determine the role of institutions on the real per capita GDP. The dynamic panel data result, especially GMM-SYS, established a longrun relationship between fiscal policy, institution, and economic growth. We found positive and statistically significant impact of aggregate of government expenditure and aggregate of other fiscal variables and institution on real per capita GDP. Furthermore, we found that there is a role of institutions on the real per capita GDP.
\end{abstract}

Keywords: Economic growth; institutions; aggregate of government expenditure; aggregate of other fiscal variables; dynamic panel cointegration.

\begin{abstract}
ABSTRAK
Artikel ini mengkaji kesan dasar fiskal dan institusi ke atas pertumbuhan ekonomi di negara-negara Asia melalui aplikasi pendekatan GMM-SYS daripada penganggar panel dinamik sebagai keutamaan analisis. Ujian dilakukan melalui
\end{abstract}


dua saluran yang berbeza yang mana dasar fiskal dapat memberi kesan jangka panjang ke atas pertumbuhan ekonomi. Saluran pertama ialah apabila aggregat perbelanjaan kerajaan, aggregat pemboleh ubah fiskal lain dan institusi dapat memberi kesan pada Keluaran Dalam Negara Kasar (KDNK) benar per kapita dan saluran kedua adalah untuk menentukan peranan institusi ke atas KDNK benar per kapita. Hasil kajian data panel dinamik terutama GMMSYS menunjukkan wujudnya hubungan jangka panjang antara dasar fiskal, institusi dan pertumbuhan ekonomi. Didapati terdapat impak yang signifikan dan positif aggregat perbelanjaan kerajaan dan aggregat pemboleh ubah fiskal lain dan institusi ke atas KDNK benar per kapita juga dapati adanya peranan institusi ke atas KDNK benar per kapita.

\section{INTRODUCTION}

Fiscal policies have a benign role for economic growth in the region, namely to provide a stable macro environment for investment. The changed environment of liquidity constraints on external borrowing and slowdown in output growth have led to new attention being directed toward the role and contribution of fiscal policy to reviving growth in the region (Gangopadhyay \& Chatterji, 2005). In the debate on economic policy, fiscal policy is predominantly viewed as an instrument to mitigate short-run fluctuations of output and employment. By a variation in government spending or taxation, fiscal policy aims at altering aggregate demand in order to move the economy closer to potential output. Fiscal policy was neither a cause of the crisis nor a critical determinant of economic growth. Nevertheless, its role in both the pre-crisis and postcrisis period in Asian countries has been seen as crucial, primarily in terms of its contribution to economic growth.

In Asian countries also, efficiency of the role of institutions is sadly lacking, and there are numerous deficiencies in the functioning of role of institutions. Institutions mostly thrive on informal networks of political and family connections. There is a certain lack of transparency and accountability in the operation of government role of institutions in Asian countries. This type of institutional operation has not only resulted in high transaction costs but has also created political and economic uncertainty in the region.

The framework of institutions comprises the legal rules and norms that constrain the behaviour of policy-makers. Legal rules and norms should also guarantee that government actions do not undermine but 
rather support the functioning of economic growth. Government actions should be limited and well constrained by appropriate institutions. Rules and norms can enhance the efficiency of fiscal policies and reduce the scope for rent seeking. Institutions can also secure the stability of fiscal policies by preventing erratic changes in deficit, tax laws, and expenditure programmes. Generally, it was concluded that there is evidence which suggested that institutions are important determinants of economic growth. Government policies and institutions seem to play an important role, policies and institutions that minimise rent-seeking and attract investment are correlated with higher growth.

There are many non-economic factors which interact with the economic growth process, i.e. institutional economics in North and Thomas (1973) and North (1990) who examined the link between economic development and institutions, while there is a tradition in political science since Lipset (1959) explained political institutions and democracy in terms of economic development.

Economic agents may interact in many different ways. Certain agents may only be able to trade with certain others; some agents may try to make inferences from the activities of others. Agents may change their expectations as a function of the expectations of the others with who they are in contact with. A first approach to analysing this sort of problem is to stay within the standard framework and to define a suitable sort of static equilibrium, which takes account of interaction. The latter may be local or global, that is, the first case agents will be limited as to whom they have contact with, while the second agents may meet any other agent.

There were three objectives of this study. The first objective was to examine the long-run relationship among fiscal policy, institutions, and economic growth. The second objective was to examine the role of institutions on economic growth, and the final objective was to examine whether institutions require complimentary factors to influence economic growth through interaction term effects. Thus, this study aimed at filling a gap in literature devoted solely to achieving the objectives using the Generalised Method of Moments (GMM) estimators developed for dynamic models of panel data, introduced by Arellano and Bond (1991), Arellano and Bover (1995), and Holtz-Eakin Newey, and Rosen (1998), and the GMM-system developed by Blundell and Bond (1998).

Our motivation of this study was to estimate an augmented Solow model of growth, adding fiscal policy and institution variables to the standard 
economic variables of the Solow model. In addition to econometric reasons, the choice of the sample and the estimation procedure was guided by the need to produce results that are comparable with the fits and residuals computed on the basis of Hoeffler (2002). Therefore, the System Generalised Method of Moments (SYS-GMM) was adopted as the preferred estimation procedure. This was in-line with Hoeffler (2002), one of the benchmark papers used in the study.

This paper is organised as follows. Section 2 contains a brief literature review. In section 3, the model is applied to the 13 Asian economies. Section 4 presents the empirical results and the last section concludes.

\section{REVIEW OF SELECTED LITERATURE}

The most recent empirical literature, mainly based on panel data regressions, showed that economic growth is significantly affected by fiscal policies, although there remains some lack of agreement on the sign of the effects. Gerson (1998) surveyed the theoretical and empirical literature on the effect of fiscal policy variables (government expenditure programmes and taxes) on economic growth. He concluded that (1) educational attainment and public health status have significant and positive effects on per capita output growth; (2) economies that are open to international trade grow faster than those that are closed, therefore fiscal policies that encourage openness should encourage growth; (3) government expenditure on physical infrastructure typically increases private sector productivity and output growth; (4) spending on defence and social services to maintain the social fabric might increase output growth if it contributes to political stability; and (5) saving and investment also appear to be relatively insensitive to changes in the rate of return, especially in developing countries.

Heller (1997) argued that capital inflows should be accompanied by cautious fiscal policy. The inflows would stimulate economic activity, as a result tax collection would increase and the fiscal balance, with unchanged expenditure, would improve. Nevertheless, fiscal contraction beyond this automatic adjustment is desirable in order to limit the expansionary pressures in the economy, to reduce the liquidity in the financial market, and to limit the exchange rate appreciation that is caused by capital inflows.

Dogan and Tang (2006) determined the direction of causality between national income and government expenditure for Indonesia, Malaysia, the 
Philippines, Singapore, and Thailand. Their results of Granger causality test indicated that government expenditures do not play a significant role in promoting economic growth in the four countries in their study, with the Philippines being the exception. Tang (2001) investigated the relationship between national income and government expenditure in Malaysia over the sample period 1960 to 1998. Results of the Johansen cointegration test indicated that there is no long-run relationship among real per capita national income and real per capita public expenditure. Therefore, Wagner thesis is not applicable in Malaysia. The Granger causality tests revealed a unidirectional causality, that is, from real per capita income growth to real per capita public expenditure growth. This indicates that Wagner's law is a short-run phenomenon in Malaysia. The implication is that, as economic activities expand, more government expenditure is required. However, there is no evidence to support the Keynesian proposition that government expenditure as a policy instrument can be used to encourage growth in the Malaysian economy.

Zagler and Dürnecker (2003) surveyed the literature on fiscal policy and economic growth. They presented a unifying framework for the analysis of long-run growth implications of government expenditures and revenues. They found that the level of education expenditure and the growth rate of public infrastructure investment both exhibit a positive impact on the growth rate of the economy. Tanzi and Zee (1997) examined systematically the various ways that the main fiscal instruments (tax policy, public expenditure policy, and budget policy) influence economic growth through their impact on the determinants of growth.

The question on how institutions fit into a theory of economic growth of course depends not only on what one means by institutions, but also on the other aspects of that theory. Rodrik, Subramaniam, and Trebbi (2002) concluded that institutions rule over other potential determinants of growth and, in particular, these geographic variables have strong impact on institutions but little or no effect on growth beyond the institutional linkage. This means that quality of institutions overrides geography and integration (international trade) in explaining cross-country income levels. Rodrik (1997) found that an index of institutional quality-drawn from the work by Knack and Keefer (1995), and Easterly and Levine (1997) - does exceptionally well in rank-ordering East Asian countries according to their growth performance.

North (1990) argued that it is the country's institutions that determine the long-run economic performance, by defining the way the political/ 
economic system operates. North identified the government's enforcement of property rights, its share of GNP, and the regulations it imposes as the most important determinants of economic performance. These institutions clearly could have a significant effect on the TFP of a country's economic system.

Leblang (1996) suggested that there is a positive correlation between economic and political freedom and economic growth. Goldsmith (1995) also concluded that both economic and political freedom is correlated with economic growth. Przeworski and Limongi (1997) found little evidence that political systems affect growth, but they did not examine economic institutions. Gwartney, Lawson, and Block (1996) developed a measure of economic freedom that is independent of political freedom, and their analysis indicated that there is a simple correlation between economic freedom and economic growth. Barro (1996) concludes that after adjusting for various economic factors, democracy has, if anything, a negative impact on economic growth. Building on this prior work, this paper seeks to identify more precisely the characteristics conducive to economic growth and the key institutional and policy factors that contribute to the differences in the growth rates across countries.

Rodrik et al. (2002) followed this analysis in treating current institutions as a stock that has been created by a past flow of good or bad policies, that is, by the operation of past institutions. Results thus rely upon current measures of the rule of law. Sala-i-Martin and Subramanian (2003) found that once the effect of resource flowing on institutions (with an emphasis on rule of law) is accounted for, resources have no effect or a small positive effect on growth rates of per capita GDP. Law and Demetriades (2006) examined whether institutions are an important determinant of financial development by using dynamic panel data techniques. They found that the institution variable is significant in determining financial development in all models.

Chen and Gupta (2006) examined the structural factors that may have an effect on economic growth. They worked with panel data where observations are pooled on a cross-section over a period of time. They began with a linear growth regression specification and then extended it to account for interaction terms. The interaction terms were between a variable to measure for openness and the various structural factors such as education, financial depth, public expenditure on education and health, and the inflation rate. They concluded that the interaction terms between openness and government expenditure on health and 
education, and between openness and financial depth have positive coefficients. This implies that in the economies where the government spends more on education and health and with a relatively developed financial system, openness will have a positive effect on growth.

Law and Demetriades (2006) found that the coefficient for the models containing the interaction term demonstrates that the interaction between capital inflows and import duties is positive and has a highly significant influence on financial development. Borensztein, De Gregorio, and Lee (1998) detected a positive and significant interaction between the stock of human capital and FDI. Eller, Haiss, and Steiner (2006) implemented a second improvement interaction term between the stock of FSFDI and the stock of human and physical capital. They found that the interaction between the FSFDI stock with the index of employee education has a positive impact on economic growth, and the interaction between the FSFDI stock with the stock of physical capital is associated negatively with growth. They also considered the positive human capital-related interaction term in their model and they discovered complementary effects between FSFDI and human capital on economic growth. Furthermore, FSFDI seems to spur economic growth as human capital stock increases.

Benos (2005) allowed for heterogeneity in the coefficients of government spending on education, health, and social services across countries. He found that the interaction term between social spending and GDP per capita is negative and statistically significant in three out of six estimations, implying that the influence of social spending on growth might weaken the higher the development level of a country. The effect of health expenditure seems to be stronger the richer a country is, although the relevant variable interaction between health expenditure and GDP is not statistically significant most of the time.

\section{EMPIRICAL SPECIFICATION}

Following Hoeffler (2002) in the Solow model, growth in output per worker depends on initial output per worker $[y(0)]$, the initial level of technology $[\mathrm{A}(0)]$, the rate of technological progress $(\mathrm{g})$, the savings rate $(\mathrm{s})$, the growth rate of the labour force $(\mathrm{n})$, the depreciation rate $(\delta)$, and the share of capital in output $(\alpha)$. Thus, the model predicts that a high saving rate will affect growth in output per worker positively, whereas high labour force growth (corrected by the rate of technological progress 
and the rate of depreciation) will have a negative effect on growth in output per worker. The basic Solow model is

$$
\ln y(t)-\ln y(0)=\ln y(0)+\ln A(0)+g t+\frac{\alpha}{1-\alpha} \ln (s)-\frac{\alpha}{1-\alpha} \ln (n+g+\delta)
$$

where $y(t)$ denotes the logarithm of output per worker in period $t$.

In the augmented version of the Solow model, investment in human capital is an additional determinant of growth in output per worker

$$
\begin{aligned}
\ln y(t)-\ln y(0)= & \ln y(0)+\ln A(0)+g t+\frac{\alpha}{1-\alpha-\beta} \ln \left(s_{k}\right)+\frac{\beta}{1-\alpha-\beta} \ln \left(s_{h}\right) \\
& -\frac{\alpha}{1-\alpha} \ln (n+g+\delta)
\end{aligned}
$$

where $s_{k}$ and $s_{h}$ denote the proportion of output invested in physical and human capital, respectively.

Equations (1) and (2), for example, have been used as the framework for empirical analysis by Mankiw, Romer and Weil (1992), Islam (1995) and Caselli, Esquirel, and Lefort (1996). In this section, a simple model is set out that provides an organising framework for thinking about the ways in which the components of fiscal policy, institutions, and interaction term affect economic growth. Therefore, this study adopted the framework introduced by Mankiw et al. (1992), Demetriades and Law (2006), Ghura and Hadjimichael (1996), Hoeffler (2002), and Knight, Loayza, and Villanuera (1993). This study provided a growth model from the conventional growth accounting framework and the production function below takes the standard neoclassical form with a minor modification as in Model 1 and Model 2 below:

\section{Model 1}

$$
\begin{aligned}
\ln Y_{i t}= & \beta_{0}+\beta_{1} \ln G E_{i t}+\beta_{2} \ln O F V_{i t}+\beta_{3} \ln I N S_{i t}+\beta_{4} \ln \left(G E_{i t} * I N S_{i t}\right)+ \\
& \beta_{5} \ln S_{k i t}-\beta_{6} \ln (n+g+\delta)_{i t}+\varepsilon_{i t}
\end{aligned}
$$

Model 2

$$
\begin{aligned}
\ln Y_{i t}= & \beta_{0}+\beta_{1} \ln G E_{i t}+\beta_{2} \ln O F V_{i t}+\beta_{3} \ln I N S_{i t}+\beta_{4} \ln \left(O F V_{i t} * I N S_{i t}\right)+ \\
& \beta_{5} \ln S_{k i t}-\beta_{6} \ln (n+g+\delta)_{i t}+\varepsilon_{i t}
\end{aligned}
$$


where $Y_{i t}$ is a real GDP per capita, $G E_{i t}$ is an aggregate of government expenditure variables as a share of GDP (obtained by summing up the government expenditure on health, education, and defence), $O F V_{i t}$ is an aggregate of other fiscal variables as a share of GDP (obtained by summing up public sector wages and salaries, expenditure on other goods and services, transfers and subsidies, interest payment on government debt, capital expenditure (minus government expenditure on health, education and defence), tax revenues, non-tax revenues, and grant), $S_{k i t}$ is the savings in physical capital, $(n+g+\delta): n$ is the rate of labour growth, $g$ is the rate of technology growth or technological progress and $\delta$ is the rate of depreciation. The addition of $g$ and $\delta$ is assumed to be constant across countries and over time, following Islam (1995), Mankiw et al. (1992), and Caselli et al. (1996), technological progress and the depreciation rate are assumed to be constant across countries and that they sum up to 0.05 . The natural logarithm of the sum of population growth is 0.05 and was calculated for $1 \mathrm{n}(n+g+$ $\delta)$. In addition, $I N S_{i t}$ is an institution indicator which is obtained by summing up the five indicators (corruption, bureaucratic quality, rule of law, government repudiation of contracts, and risk of expropriation), $G E_{i t}{ }^{*} I N S_{i t}$ and $A F V_{i t}{ }^{*} I N S_{i t}$ are interactions between the aggregate of government expenditure variables and institutions and the aggregate of other fiscal variables and institutions, $i$ is a cross-section data for countries referred to, and $t$ is a time series data, $\varepsilon_{\mathrm{it}}$ is an error term. The constant is denoted as $\beta_{0}$ while $\beta_{1}$ to $\beta_{6}$ are the coefficients showing how much a one unit increase in each individual variable will affect the growth rate in economic growth.

\section{Dynamic Panel Data Analysis Procedure}

Following Hoeffler (2002), in a panel data model, we can explicitly account for permanent unobserved country specific effects, $\eta_{i}$. This provides a panel data model of the form

$$
y_{i, t}=\alpha+\beta y_{i, t-1}+x_{i t}+\eta_{i}+v_{i t}
$$

where $y_{i, t}$ denotes the growth rate of real per capita GDP, $y_{i, t-1}$ is the initial level of real per capita GDP, $t$ denotes points in time $t=2, \ldots \mathrm{T}$. For example $y_{i, t}$ may reflect the average growth rate over a series of four-year periods, with $y_{i, t-1}$ being the level of real per capita GDP at the beginning of these periods, and $X_{i t}$ being measured either at the 
beginning of each period, or as an average over each of the four-year periods.

Since the relevant four-year growth rate in Equation (5) is a logarithmic difference of GDP per capita, we have the following dynamic panel data model

$$
y_{i t}-y_{i, t-1}=\alpha+\beta y_{i, t-1}+x_{i t}+\eta_{i}+v_{i t}
$$

or equivalently

$$
y_{i t}=\alpha+\beta^{*} y_{i, t-1}+x_{i t}+\eta_{i}+v_{i t}
$$

where $\beta^{*}=(\beta+1)$. It is important to note that the typical panel in the study of economic growth has a small number of time series periods, i.e. $\mathrm{T}$ is small.

\section{OLS Levels Estimation and Within Groups Estimation}

In this section, the study adopted the autoregressive model from Bonds (2002), compromising the estimation of the following equation:

$$
y_{i t}=\alpha y_{i, t-1}+\left(\eta_{i}+v_{i}\right), \quad|\alpha|<1 ; i=1,2, \ldots, N ; t=2,3, \ldots, T
$$

where $y_{i t}$ is an observation on some series for individual $i$ in period $t$, $y_{i, t-1}$ is the observation on the same series for the same individual in the previous period, $\eta_{i}$ is an unobserved individual-specific time-invariant effect which allows for heterogeneity in the means of the $y_{i t}$ series across individuals, and $v_{i t}$ is a disturbance term. A key assumption that was maintained throughout is that the disturbances $v_{i t}$ are independent across individuals.

As Hsiao (1986) showed, omitting unobserved time invariant country effects in a dynamic panel model will cause OLS level estimate to be biased and inconsistent. The lagged dependent variable, $y_{i, t-1}$, is positively correlated with the permanent effects, $\eta_{i}$. As a result, the OLS level estimate of coefficient $\beta^{*}$ in the typical regression is likely to be biased upward (Hoeffler, 2002). 
Alternatively, the within groups estimator differentiates all variables from their respective time means. It is assumed that all right-hand side variables are strictly exogenous, which is violated at least by the lagged variable. As such, it introduces a significant correlation between non-exogenous variables and the time-demeaned error term (Bonds, 2002), which decreases as the number of periods tends towards infinity (Baltagi, 1995). The within groups estimator eliminates this source of

inconsistency by transforming the equation to eliminate $\eta_{i}$. Specifically the mean values of $y_{i t,} y_{i, t-1}, \eta_{i}$ and across $T-1$ observations for each individual $i$ are obtained, and the original observations are expressed as deviations from these individual means. Within groups estimator is also inconsistent and standard results for omitted variables bias would indicate that, at least in large samples, the within groups estimate $\hat{\beta}^{*}$ is likely to be biased downward (Bonds, 2002). Consequently, the estimate of $\hat{\beta}^{*}$ obtained from OLS levels can be regarded as an approximate upper bound on this coefficient, and the estimate obtained from within groups estimation can be regarded as an approximate lower bound (Hoeffler, 2002).

\section{GMM Estimators for Dynamic Panel Data Model}

The GMM estimator proposed by Arellano and Bond (1991), known as two-step estimation, is constructed in two phases. Firstly, first differenced regressions and/or instruments from the dynamic panel data model are calculated to control for unobserved effects; then, secondly, using lagged observation values of the right-hand side explanatory variables in levels as their instruments. With lagged dependent variable and other endogenous regressors, the lagged levels are dated $t-2$ and earlier. If there are predetermined regressors, all their lagged levels are used as instruments.

Consider the panel data model specification

$$
\begin{aligned}
& y_{i t}-y_{i, t-1}=\left(\beta^{*}-1\right) y_{i, t-1}+\chi_{i t}+u_{i t} \\
& u_{i t}=\eta_{i}+v_{i t}
\end{aligned}
$$


where $y_{i, t}$ is the logarithm of dependent variables, $x_{i, t}$ is the set of other endogenous variable, $u_{i t}$ is the time-specific effects, $\eta_{i t}$ is the country-specific effects, and $v_{i t}$ is the error term; for $\mathrm{i}=1, \ldots, \mathrm{N}, \mathrm{t}=2$,

$\ldots \mathrm{T}$. The single regressor $x_{i t}$ is correlated with $\eta_{i}$ and predetermined with respect to $\varepsilon_{i t}$ meaning that $E\left(x_{i t} v_{i t+s}\right)=0, s=0, \ldots, T-t$ but $E\left(x_{i t} v_{i t+s}\right) \neq 0, r=1, \ldots, t-1$. A commonly used estimator is the GMM estimator in the model in first difference (Arellano \& Bond, 1991),

$$
\Delta y_{i t}=\beta^{*} \Delta y_{i, t-1}+\gamma \Delta x_{i t}+\Delta u_{i t} ; \quad t=2, \ldots, T
$$

After accounting for the time-specific effects and grouping all explanatory variables in a vector $x$, Equations (9), (10), and (11) can be rewritten as:

$$
\Delta y_{i t}=\beta * \Delta y_{i, t-1}+\gamma \Delta x_{i t}+\Delta \eta_{i t}+\Delta v_{i t}
$$

The estimation of cross-country effects is based on a regression on timeaveraged data. In order to sweep out unobserved individual country specific effects $\eta_{i}$ that are a source of inconsistency in the estimates and specified and in order to obtain a consistent estimate of $\beta^{*}$ as $N \rightarrow \infty$ for fixed $\mathrm{T}$ we take first difference of Equation (7).

$$
y_{i t}-y_{i t-1}=\beta^{*}\left(y_{i t-1}-y_{i t-7}\right)+\gamma\left(x_{i t}-x_{i t-1}\right)+\left(v_{i t}-v_{i t-1}\right)
$$

Since the differenced lagged dependent variable and the differenced error term are correlated OLS estimation of Equation (13) will not produce a consistent estimate of $\beta *$, even if the regressor, $x_{i, t}$ is strictly exogenous.

The GMM estimator suggested by Arellano and Bond (1991) is known to be rather inefficient when instruments are weak because it makes use of the information contained in differences only. Blundell and Bond (1998) suggested making use of additional level information besides the differences. The combination of moment restrictions for differences and levels results in an estimator called the GMM-system estimator by Arrellano and Bond.

Following Arellano and Bond (1991) and Hoeffler (2002), we can use values of the predetermined $x_{i t}$ lagged one period or more as valid instruments 
in the first differenced growth equation. It is also straightforward to treat, for example, investment as an endogenous variable. This means that we are allowing for correlation between current investment and current shocks to GDP, as well as feedback from past shocks to GDP, i.e.

$$
\begin{array}{ll}
E\left(x_{i t} v_{i s}\right) \neq 0 & \text { for } s \leq t \\
\text { and } & \\
E\left(x_{i t} v_{i s}\right)=0 & \text { for } s>t \text { only }
\end{array}
$$

In this case, the valid instruments in the differenced equation are values of the endogenous $x_{i t}$ lagged two periods or more.

Blundell and Bond (1998) showed that estimators relying on lagged levels as instruments for current differences are likely to perform poorly when the series are close to a random walk. In this case, the available instruments are only weakly correlated with the endogenous variables, and the GMM estimator is likely to suffer from serious finite sample bias, as well as imprecision (Hoeffler, 2002). Instead, they suggested estimating a system by combining two sets of equations. One set of equations is the differenced equation (13)

$$
y_{i t}-y_{i, t-1}=\beta *\left(y_{i, t-1}-y_{i, t-2}\right)+\gamma\left(x_{i t}-x_{i, t-1}\right)+\left(v_{i t}-v_{i, t-1}\right)
$$

We used lagged levels of $y_{i t}$ and $x_{i t}$ as instruments, as discussed for the first differenced GMM estimation. The other set of equations in the system is the levels equation, which is Equation (12)

$$
y_{i t}=\alpha+\beta^{*} y_{i, t-1}+\gamma x_{i t}+\eta_{i}+v_{i t}
$$

provided the $x_{i t}$ regressor satisfies

$$
E\left(\Delta x_{i t} \eta_{i}\right)=0
$$

and the initial conditions satisfy the restriction

$$
E\left(\Delta y_{i 2} \eta_{i}\right)=0
$$

Arellano and Bover (1995) proposed the estimators of $\Delta y_{i, t-1}$ and $\Delta x_{i t}$ as instruments in the level equation. It is assumed that equation (16) allows the level of $x_{i t}$ to be correlated with the unobserved country specific effects, $\eta_{i}$, but requires the changes in $x_{i t}$ to be uncorrelated with $\eta_{i}$. 
The consistency of the GMM estimators depends on whether lagged values of the explanatory variables are valid instruments in the growth regression. This issue was addressed by considering two specification tests suggested by Arellano and Bond (1991) and Arellano and Bover (1995). The first is a Sargan test of over-identifying restrictions, which tests the overall validity of the instruments. Failure to reject the null hypothesis gives support to the model. The second test examines the null hypothesis that the error term is not serially correlated. As with the Sargan test, the model specification is supported when the null hypothesis is not rejected. In the system specification, we test whether the differenced error term (that is, the residual of the regression in differences) is second-order serially correlated. Second-order serial correlation of the differenced residual would indicate that the original error term is serially correlated and follows a moving average process at least of order one. This would reject the appropriateness of the proposed instruments (and would call for higher-order lags to be used as instruments).

The test statistics of $\mathrm{AR}(1)$ and $\mathrm{AR}(2)$ test for the presence of serial correlation in the first differenced residuals of first and second order, respectively. They are asymptotically normally $N(0,1)$ distributed under the null of no serial correlation (Arellano \& Bond, 1991). First order autocorrelation $\mathrm{AR}(1)$ is expected to be negatively significant but according to the second order autocorrelation AR(2) test, it is not significant, which is the crucial point with respect to the validity of the instruments.

\section{DATA AND CHOICE OF VARIABLES}

The data set consisted of a panel of observations for 13 Asian countries ${ }^{1}$ for the period 1982-2001. The dependent variable is chosen as real GDP growth per capita in all sets of regressions. To account for the lag between the initial level of per capita GDP, average savings and average population growth rate (adjusted for the depreciation rate and the rate of technological progress), aggregate of government expenditure variables, aggregate of other fiscal variables, and institutions and the effect on output growth, we used a four-year forward moving average to eliminate business cycle type short-run fluctuations induced by the shifts in these explanatory variables, and this also increases the number of time series 
observations in our panel data. As pointed out by Devarajan, Swaroop, and Zou (1996), the five-year forward lag structure addresses the joint endogeneity of variables and the possibility of reverse causality. In that sense, the joint endogeneity of our explanatory variables and economic growth is an issue that should be taken more seriously in our framework.

Annual data were collected from the World Development Indicator, Asian Development Bank, and The Government Finance Statistics. Following Demetriades and Law (2006), the data set on institutional quality indicators are obtained from the International Country Risk Guide. The first three variables are scaled from 0 to 6 , whereas the last two variables are scaled from 0 to 10 . Higher values indicate better ratings for institutional quality and vice versa. The scale of corruption, bureaucratic quality and rule of law was first converted to 0 to 10 (multiplying them by $5 / 3$ ) to make them comparable to the other indicators. The institution indicator is obtained by summing up the above five indicators.

\section{EMPIRICAL RESULTS}

In this section, results are presented for the dynamic panel data estimators of Model 1 and Model 2 in Table 1 and Table 2, respectively. Results will be outlined for GMM estimation in difference (DIF) and system (SYS) versions and also the OLS level and within groups estimation techniques. Table 1 and Table 2 report our results for Model 1 and Model 2 which are a version of the augmented Solow model, where the logarithm of the aggregate of government expenditure, aggregate of other fiscal variables, institutions, and the interaction terms between the aggregate of government expenditure and institutions and between the aggregate of other fiscal variables and institutions are included as additional explanatory variables.

\section{OLS and Within Groups Results}

Models in Table 1 and Table 2 follow the suggestion of Arellano and Bond (1991) and Blundell and Bond (1998; 1999), where all regressions include time dummies which we found to be jointly significant in every regression. The tables show the parameter estimates (in parenthesis), the standard errors of the parameter estimates (robust to arbitrary forms of cross-sectional and time-series heteroskedasticity) and a selection of diagnostic statistics. 
In Table 1 and Table 2, the left-hand side variable is the change in the logarithm of explanatory variables. We begin our analysis with an OLS regression in column 2 through Table 1 and Table 2, the estimates of the coefficients for the initial per capita GDP (1n rgdp $i t-1)$ are negative, -2.042 (Model 1) and -2.039 (Model 2), and statistically significant at 1\% level for both models. The negative coefficient on initial GDP as in most published growth regressions is interpreted as conditional convergence as suggested by the Solow model (Hoeffler, 2002).

In Table 1 and Table 2, the estimated coefficients for the aggregate of other fiscal variables $(\ln O F V$ ) are positive, 0.202 (Model 1) and 0.170 (Model 2), and statistically significant at the $5 \%$ level in both models. The estimates of the coefficients for the aggregate of government expenditure (1n GE) are positive, 2.093 (Model 1) and 2.324 (Model 2), and statistically significant at the 1\% level in Model 1 and significant at the $5 \%$ level in Model 2. Thus, the aggregate of government expenditure and aggregate of other fiscal variables have a positive and significant effect on real per capita GDP growth.

We found that the estimates of the coefficients for the institutions (ln ins) are positive, 2.269 (Model 1) and 1.107 (Model 2), and statistically significant at the $5 \%$ level in both models. Thus, institutions have a positive and significant effect on real per capita GDP growth. The interaction terms try to identify whether institutions require complimentary factors to influence economic growth. We found that the interaction terms included, between institutions and the aggregate of government expenditure (1n GE*ins) and between institutions and the aggregate of other fiscal variables ( $\ln O F V^{*}$ ins $)$ have positive coefficients [1.414 (Model 1) and 0.435 (Model 2)] and statistically significant at the 1 and $5 \%$ levels in Model 1 and Model 2, respectively. Again we found that the inclusion of interaction term between the aggregate of government expenditure and institutions, and between the aggregate of other fiscal variables and institutions as added regressors in the growth equations (Model 1 and Model 2) does not generally affect the sign or absolute magnitude of the estimates; they are not less precisely estimated than their counterparts in Model 1 or Model 2. These results imply that economies where the government gives more attention to the aggregate of government expenditure and the aggregate of other fiscal variables, institutions will have a positive effect on economic growth. 
By assuming that the savings in physical capital (investment) $\left(\ln s_{k}\right)$ is potentially endogenous variable and current population growth rate is potentially exogenous variable, these estimates already allow for the possibility of serially uncorrelated measurement error in either of these explanatory variables. In Table 1 and Table 2, we found that the estimated coefficients for the savings in physical capital (investment) $\left(\ln s_{k}\right)$ are positive for both models, 0.988 (Model 1) and 0.855 (Model 2 ), and statistically significant at the $1 \%$ level for both models. Therefore,

this indicates that savings in physical capital (investment) $\left(\ln s_{k}\right.$ ) has a significantly positive effect on the steady state level of per capita GDP growth. Column 2 in Table 1 and Table 2 also shows that the coefficients of population growth $(1 \mathrm{n}(n+g+\delta))$ are negative, -0.937 (Model 1) and -0.994 (Model 2), and statistically significant at the 1\% level in both models. This is in-line with the neoclassical growth model that predicts that as population increases, the steady state level of per capita GDP will decline through the lowering of the capital labour ratio. Thus, our findings here is also in line with Solow model, where the negative coefficient on initial GDP as in most published growth regressions is interpreted as conditional convergence, while investment is positive and population growth is negative.

Overall, based on the results presented in Table 1 and Table 2, and the arguments presented above, in accordance with expectations in the presence of firm-specific fixed effects, OLS panel estimates seem to deliver an upward-biased estimate of the lagged dependent variable coefficient.

The results of the analysis with a within groups estimator are shown in the third and seventh column of Table 1 and Table 2. We found that the estimated coefficients for the initial per capita GDP (1n $\left.r g d p_{i t-1}\right)$ are negative, -2.485 (Model 1) and -2.391 (Model 2), and statistically significant at $1 \%$ level for both models. Same as in the OLS estimates, the negative coefficient on the initial GDP as in most published growth regressions is interpreted as conditional convergence as suggested by the Solow model. Therefore, comparing the estimated coefficient of the OLS level regression and the within groups estimation, it was found that the OLS level provides a higher estimate for the coefficients of the initial real per capita GDP than the within groups estimation for all models in all tables. 
In Table 1 and Table 2, the estimated coefficients for the aggregate of other fiscal variables $(\ln O F V)$ are positive, 0.642 (Model 1) and 0.167 (Model 2), and statistically significant at the 5\% level in both models. For the aggregate of government expenditure , (1n GE) the estimated coefficients are positive, 2.568 (Model 1) and 1.877 (Model 2), and statistically significant at the $5 \%$ level in both models. Thus, the aggregate of government expenditure and the aggregate of other fiscal variables have positive and significant effects on real per capita GDP.

Column 3 in Table 1 and Table 2 for the within groups estimation shows that the coefficients for institutions are positive $(\ln i n s), 2.512$ (Model 1) and 1.075 (Model 2), and statistically significant at the 5\% level which are the same as the results from the OLS estimation. The estimated coefficients

for the savings in physical capital (investment) $\left(\ln s_{k}\right)$ are positive, 0.997 (Model 1) and 0.936 (Model 2), and statistically significant at the one percent level in both models. The coefficients for the population growth $(1 \mathrm{n}(n+g+\delta))$ are negative, -1.024 (Model 1) and 0.936 (Model 2), and statistically significant at the $1 \%$ level in both models. Thus, institutions and savings in physical capital have a positive and significant effect on real per capita GDP growth, and population growth is negative and has a significant effect on real per capita GDP growth.

Table 1: Estimation of Model 1; Dependent variable $\Delta$ 1n $r g d p c_{i t}$

\begin{tabular}{lcccc}
\hline & OLS & Within Groups & DIF-GMM & \multicolumn{1}{c}{ SYS-GMM } \\
\hline 1n rgdpc ${ }_{(t-1)}$ & $-2.042^{*}(0.328)$ & $-2.485^{*}(0.243)$ & $-2.176^{*}(0.893)$ & $-0.858^{*}(0.017)$ \\
1n GE & $2.093^{*}(1.976)$ & $2.568^{* *}(1.521)$ & $1.703^{*}(0.336)$ & $0.937^{*}(0.362)$ \\
1n OFV & $0.202^{* *}(0.188)$ & $0.642^{* *}(0.271)$ & $0.523^{* *}(0.191)$ & $0.207^{*}(0.089)$ \\
1n ins & $2.269^{* *}(0.741)$ & $2.512^{* *}(0.493)$ & $2.476^{*}(0.528)$ & $1.686^{*}(0.723)$ \\
1n $s_{k}$ & $0.988^{*}(0.264)$ & $0.997^{*}(0.233)$ & $0.510^{*}(0.349)$ & $0.439^{*}(0.186)$ \\
1n $(n+g+\delta)$ & $-0.937^{*}(0.281)$ & $-1.024^{*}(0.269)$ & $-0.043^{*}(0.991)$ & $-0.690^{*}(0.318)$ \\
1n $\left(G E E^{*}\right.$ ins $)$ & $1.414^{*}(0.294)$ & $1.071^{*}(0.240)$ & $0.427^{*}(0.128)$ & $1.403^{*}(0.409)$ \\
No. of obs. & 52 & 52 & 52 & 52 \\
Wald test: & $5944 .{ }^{*}(0.000)$ & $5981 .^{*}(0.000)$ & $3314 .{ }^{*}(0.000)$ & $762.9^{*}(0.000)$ \\
Sargan test: & - & - & $36.9(0.509)$ & $154.3(0.164)$ \\
AR(1) test: & $-1.893^{* *}(0.058)$ & $-2.305^{* *}(0.021)$ & $-2.720^{*}(0.007)$ & $-2.095^{*}(0.006)$ \\
AR(2) test: & $-1.059(0.290)$ & $1.344(0.179)$ & $0.01103(0.991)$ & $0.8046(0.421)$ \\
\hline
\end{tabular}

Notes: Heteroskedasticity consistent standard error is reported in parentheses; ${ }^{*},{ }^{* *}$, and ${ }^{* * *}$ denote significance at $1 \%, 5 \%$, and $10 \%$ levels, respectively. Time dummies and constant are included. The figures reported for the tests of first and second order correlation under the System-GMM column (AR (1) and AR (2)) as well as for the Wald test and Sargan test are the p-values of the null hypothesis. 


\section{First Differenced GMM and System GMM Results}

Hoeffler (2002) argued that for special cases of spherical disturbances, the one-step and two-step GMM estimators are asymptotically equivalent for the first-differenced estimator (Arellano \& Bond, 1991). In this case the two-step estimator is more efficient. Therefore, Column 4 presents the results using the Arellano and Bond (1991) first differenced GMM estimator in Table 1 and Table 2 for all models. It was assumed that the initial GDP is predetermined and investment is endogenous. We also assume that current population growth is exogenous, in the sense of being uncorrelated with shocks to GDP per capita. This allows the use of both the current and lagged levels of population growth as instruments in the first differenced equation. The OLS level will give an estimate of $\beta$ that is biased upwards in the presence of individual-specific effects (Hsiao, 1986) and the within groups will give an estimate of $\beta *$ that is seriously biased downwards in short panels (Nickell, 1981). Thus, a consistent estimate of $\beta^{*}$ can be expected to lie between the OLS levels and the within groups estimates. If we observe that the first differenced GMM estimate is close to or below the within groups estimate, it seems likely that the GMM estimate is also biased downwards in our application, perhaps due to weak instruments.

In Column 4 from Table 1 and Table 2, it was found that all coefficients are positive and statistically significant at the 1 and $5 \%$ levels, except the coefficient of population growth $(1 \mathrm{n}(n+g+\delta))$, which is negative and statistically significant at the one percent level. From these tables, it was found that the first differenced GMM estimates of the coefficients on the initial real per capita GDP in both tables are negative, -2.176 (Model one) and -2.104 (Model two), and statistically significant at the $1 \%$ level in both models. These results are close to the within groups estimates. Therefore, it can be concluded that the case for the first differenced GMM estimate seems to be downward biased, because it is very close to the within group estimate, which is expected to be seriously biased downwards in short panels with six or fewer time periods (Nickell, 1981). 
Table 2: Estimation of Model 2; Dependent variable $\Delta$ 1n $\operatorname{rgdpc}_{i t}$

\begin{tabular}{lcccc}
\hline & OLS & Within Groups & DIF-GMM & \multicolumn{1}{c}{ SYS-GMM } \\
\hline $1 \mathrm{n} r g d p c_{(t-1)}$ & $-2.039^{*}(0.348)$ & $-2.391^{*}(0.391)$ & $-2.104^{*}(0.434)$ & $-0.862^{*}(0.019)$ \\
$1 \mathrm{n} G E$ & $2.324^{* *}(1.547)$ & $1.877^{* *}(1.700)$ & $0.689^{*}(0.154)$ & $1.245^{*}(1.076)$ \\
$1 \mathrm{n} F P$ & $0.170^{* *}(0.088)$ & $0.167^{* *}(0.078)$ & $0.109^{* *}(0.060)$ & $0.204^{*}(0.068)$ \\
$1 \mathrm{n}$ ins & $1.107^{* *}(0.486)$ & $1.075^{* *}(0.481)$ & $0.156^{*}(0.909)$ & $1.088^{*}(0.353)$ \\
$1 \mathrm{n} s_{k}$ & $0.855^{*}(0.312)$ & $0.936^{*}(0.308)$ & $0.599^{* *}(0.240)$ & $0.537^{*}(0.188)$ \\
$1 \mathrm{n}(n+g+\delta)$ & $-0.994^{*}(0.269)$ & $-1.104^{*}(0.326)$ & $-0.708^{*}(0.259)$ & $-0.811^{*}(0.414)$ \\
$1 \mathrm{n}\left(\right.$ OFV ${ }^{*}$ ins $)$ & $0.435^{* *}(0.254)$ & $0.398^{* *}(0.239)$ & $0.084^{*}(0.023)$ & $0.051^{*}(0.018)$ \\
No. of obs. & 52 & 52 & 52 & 52 \\
Wald test: & $7780 .{ }^{*}(0.000)$ & $579.0^{*}(0.000)$ & $3023 .^{*}(0.000)$ & $1481 *^{*}(0.000)$ \\
Sargan test: & - & - & $26.0(0.658)$ & $131.1(0.384)$ \\
AR(1) test: & $-2.085^{* *}(0.037)$ & $-2.343^{* *}(0.019)$ & $-2.803^{*}(0.005)$ & $-1.467^{*}(0.003)$ \\
AR(2) test: & $-1.592(0.111)$ & $0.2773(0.782)$ & $-1.296(0.195)$ & $-0.9953(0.320)$ \\
\hline Notes: Heteroskedastity
\end{tabular}

Notes: Heteroskedasticity consistent standard error is reported in parentheses; * **, and *** denote significance at the $1 \%, 5 \%$ and $10 \%$ levels, respectively. Time dummies and 'constant are included. The figures reported for the tests of first and second order correlation under the System-GMM column (AR (1) and AR (2)) as well as for the Wald test and Sargen test are the $\mathrm{p}$-values of the null hypothesis.

The estimated coefficients for the aggregate of other fiscal variables (ln $O F V$ ) are positive, 0.523 (Model 1) and 0.109 (Model 2), and statistically significant at the $5 \%$ level. The aggregate of government expenditure 1n GE is positive, 1.703 (Model 5) and 0.689 (Model 6), and statistically significant at the 1\% level. Table 1 and Table 2 also show that the coefficients for institutions ( $\ln i n s)$ are positive and statistically significant at the $1 \%$ level in Model 1 and Model 2. The interaction terms between institutions and the aggregate of government expenditure $1 \mathrm{n} G E^{*}$ ins , and between institutions and the aggregate of other fiscal variables (ln $O F V^{*}$ ins) have positive coefficients, 0.427 (Model 1) and 0.084 (Model 2), and statistically significant at the $1 \%$ level. Thus, while the inclusion of interaction term between aggregate of government expenditure and institutions, and aggregate of other fiscal variables and institutions as an added regressor in the growth equations (Model 1 and Model 2) does not generally affect the sign or absolute magnitude of the estimates, they are not less precisely estimated than their counterparts in Model 1 or Model 2. It was concluded that the aggregate of other fiscal variables and the aggregate of government expenditure have a 
positive and significant effect on real per capita GDP growth. It was also found that the aggregate of other fiscal variables and the aggregate of government expenditure variables interact with institutions variable and could have a potential impact on long-run steady-state levels of growth.

In Table 1 and Table 2, the estimated coefficients for the savings in physical capital (investment) ( $\ln s_{k}$ ) are positive, 0.510 (Model 1) and 0.599 (Model 2), and statistically significant at the 1 and $5 \%$ levels in Model 1 and Model 2, respectively. The coefficients of population growth $(1 \mathrm{n}((n+g+\delta))$ are negative, -0.043 (Model 1) and -0.708 (Model 2), and statistically significant at the $1 \%$ level for both models. Again it was found that the results for the savings in physical capital (investment) and population growth in first differenced GMM are in-line with the Solow model. Specifically, the negative coefficient on initial GDP as in most published growth regressions is interpreted as conditional convergence, while investment is positive and population growth is negative.

As mentioned previously, differenced GMM results potentially suffer from a bias in the direction of within groups results, due to weak instruments, related with persistent time series. In such case, GMM-SYS results would be preferable. The presented results do not seem to point toward a major problem, since the GMM-DIF estimations are situated quite central amongst the two extremes of OLS and within groups. This leads to the conclusion that the system GMM results shown in Table 1 and Table 2 are to be the preferred parameter estimates.

The system GMM estimator thus combines the standard set of explanatory variables in first differences with suitably lagged levels as instruments, with an additional set of explanatory variables in levels with suitably lagged first differences as the instrument. As an empirical matter, the validity of these additional instruments can be tested using standard Sargan tests of over-identifying restriction (Arellano \& Bond, 1991). For system GMM, the two-step estimator is always more efficient than the one-step estimator. However, Monte Carlo studies show that the efficiency gain is small and that the two-step estimator converges only slowly to its asymptotic distribution. In finite samples, the asymptotic standard errors associated with the two-step GMM estimator can be seriously biased downward (Blundell \& Bond, 1998). Therefore, we followed Hoeffler (2002) who preferred to report the one-step estimates. The fifth column of Table 1 and Table 2 reports the results from system GMM, again treating investment as endogenous and population growth 
as exogenous in the sense described before. The estimated coefficient of the initial real per capita GDP is not obviously biased which lies well above the within groups estimate and well below the OLS levels estimate, and the estimates of the coefficients are more precise than the ones obtained from the first differenced GMM. This study agreed with Hoeffler (2002) that the additional instruments using the system GMM estimator appear to be both valid and highly informative in this context.

In Column 5, the estimated coefficients for the aggregate of other fiscal variables (1n FP) are positive, 0.207 (Model 1) and 0.204 (Model 2), and statistically significant at the $1 \%$ level. The aggregate of government expenditure (1n GE) is positive, 0.937 (Model 1) and 1.245 (Model 2), and statistically significant at the 1\% level. Table 1 and Table 2 also show that the coefficients of institutions ( $\ln$ ins) are positive, 2.476 (Model 1) and 0.156 (Model 2), and statistically significant at the $1 \%$ level. The interaction terms between institutions, and the aggregate of government expenditure (1n GE* ins) and institutions, and the aggregate of other fiscal variables (ln $O F V^{*}$ ins) have positive coefficients, 1.403 (Model 1) and 0.051 (Model 2), and statistically significant at the 1\% level. Again, it was found that the aggregate of other fiscal variables and aggregate of government expenditure have a positive and significant effect on real per capita GDP growth in system GMM. In this system GMM, it was also found that the aggregate of other fiscal variables and the aggregate of government expenditure variables interact with the institution variable, and could have a potential impact on the long-run steadystate levels of growth. It was concluded that when the inclusion of the interaction terms between the aggregate of government expenditure and institutions and the aggregate of other fiscal variables and institutions as added regressors in the growth equations (Model 1 and Model 2) does not generally affect the sign or absolute magnitude of the estimates.

In Table 1 and Table 2, as expected, the estimates of the coefficients for the savings in physical capital (investment) $\left(\ln s_{k}\right.$ ) are positive, 0.439 (Model 1) and 0.537 (Model 2), and statistically significant at the $1 \%$ level in both models. The coefficients on population growth $(1 \mathrm{n}((n+g+\delta))$ are negative, -0.690 (Model 1) and -0.811 (Model 2), and statistically significant at the $1 \%$ level for both models. Our results matched many studies which control capital accumulation by including the rate of investment or savings. Levine and Renelt (1992) argued that 
the positive correlation between growth and the share of investment in GDP is one of the few robust findings from the cross-country growth regression literature. On the other hand, there are many growth studies that accounted for population growth. The effect of population growth on the growth in GDP per capita tended to be negative in some studies, but this finding is rather fragile (Levine \& Renelt, 1992). Therefore, it was concluded that system GMM savings in physical capital have a positive and significant effect on real per capita GDP growth, and population growth is negative and has significant effect on real per capita GDP growth.

The Wald tests of the joint significance of the variables as well as the tests for autocorrelation and the Sargan test confirmed that the GMM estimator estimated for Model 1 and Model 2 in Table 1 and Table 2 are appropriate. First-differencing introduces AR(1) serial correlation when the time-varying component of the error term in levels is serially uncorrelated (Arellano \& Bond, 1991). Therefore, GMM estimator is consistent only when second-order correlation is not significant, although first-order correlation need not be zero. Again, the first and second order serial correlations tests are all satisfied.

\section{CONCLUSION}

Several important conclusions can be drawn from the study. Firstly, this study attempted to identify the important role of institutions government anti-diversion policies a weighted average of (i) corruption in government, (ii) rule of law, (iii) bureaucratic quality, (iv) repudiation of government contract, and (v) expropriation risk - in determining economic growth in a sample of 13 Asian countries. While the inclusion of institutions as an added regressor in the growth equations does not generally affect the sign or absolute magnitude of the estimates, they are not less precisely estimated than their counterparts. This is not surprising given that institutions are positively correlated with some of the regressors. The results from the analysis were significant, and provided support for the historical evidence presented by North and Thomas (1973), Rosenberg and Birdzell (1986), and North (1990). They showed that the security of property rights provides incentives for economic growth in the world. Secure role of institutions also lead to an efficient allocation of fiscal policy.

Secondly, this study provided another framework of a set of linkages to capture most of the important interactions among economic growth, institutions, and fiscal policy. Economic indicators interact especially 
with non-economic indicators. The positive results of the effect of the interaction terms between the aggregate of government expenditure and institutions and the aggregate of other fiscal variables and institutions on economic growth in 13 Asian economies are really interesting. These interaction terms as added regressors in the growth equations do not generally affect the sign or absolute magnitude of the estimates, they are not less precisely estimated than their counterparts. These results support earlier findings from other researchers who stated that typically economic agents in models of interaction are thought of as being placed on a lattice and interacting with their neighbours (Durlauf, 1990; Benabou, 1996; Blume, 1993; Ellison, 1993; Brock \& Durlauf, 2001.

We learned about the appropriate interaction between those two policies which are fiscal policy and institutions in the context of economic growth under an Augmented Solow model. Economists have also become more convinced that fiscal policies have significant effect on the economy. Fiscal policy affects the success of economic growth in various ways: through its impact on general confidence in institutions, and through modifying the long-term conditions for economic growth and institutions. Another important aspect of the interaction between fiscal policy and institutions is the need for a high degree of coordination in response to economic growth.

The strength and direction of interaction are determined by a second variable, institutions. The strongest evidence was for causal links that go from changes in fiscal policy and institutions, which then further affects economic growth. Thus, for institutions to play an effective role in economic growth, fiscal policy must be in place that directs management of economic activities, such as government expenditure and other fiscal variables. The interaction terms in Model 1 and Model 2 were positive, suggesting that institution and government expenditures, and other fiscal variables support each other in promoting economic growth of Asian countries. The estimation results suggested that efficient institutions play a particularly significant role in avoiding fiscal loosening, and to raise economic efficiency and growth, and thus to improve the overall fiscal position. The interaction between institutions and fiscal policy to enhance economic scrutiny with institutional reform to strengthen fiscal frameworks, can be a mutually reinforcing means of improving fiscal policies and economic growth.

Thirdly, we assessed the empirical evidence on the link between fiscal policy and growth by considering two aggregate variables, which are the aggregate of government expenditure (the sum of government 
expenditure on health, education, and defence) and the aggregate of other fiscal variables in five policy areas: public sector wages and salaries, expenditure on other goods and services, transfers and subsidies, interest payments on government debt, capital expenditure (minus government expenditure on health, education, and defence), tax revenues, non-tax revenues, and grants. The analyses of these fiscal policies in 13 Asian economies showed that the authorities do make active use of fiscal policy. This implies that fiscal policy is practically possible and can be effective in influencing the real per capita GDP. There is thus a rationale for fiscal policy.

\section{END NOTES}

1. The countries chosen for our study were as follows: China, Hong Kong, Korea, Japan, Indonesia, Malaysia, the Philippines, Singapore, Thailand, Bangladesh, India, Pakistan, and Sri Lanka.

\section{REFERENCES}

Arellano, M., \& Bond, S. (1991). Some tests of specific action for panel data: Monte Carlo evidence and an application to employment Equations. Review of Economic Studies, 58, 277-297.

Arellano, M., \& Bover, O. (1995). Another look at the instrumental variable estimation of error-component models. Journal of Econometrics, 68, 29-52.

Baltagi, B.H. (1995). Econometric analysis of panel data. New York, John Wiley and Sons.

Barro, R.J. (1996). Democracy and growth. Journal of Economic Growth, 1(1), 1-27.

Benabou, R. (1996). Heterogeneity, stratification and growth: Macroeconomic implications of community structure and school finance. American Economic Review, 86, 584-609.

Benos, K. (2005). Fiscal policy and economic growth: Empirical evidence from OECD Countries. University of Cyprus, Discussion Paper 2005-01.

Blume L. (1993). The statistical mechanics of strategic interaction. Games and Economic Behaviour, 5, 387-424.

Blundell, R.W., \& Bond, S.R. (1998). Initial conditions and moment restrictions in dynamic panel data models. Journal of Econometrics, $87,115-143$. 
Blundell, R.W., \& Bond, S.R. (1999). GMM estimation with persistent panel data: An application to production functions. Cemmap Working Paper, CW99/4. London: Institute for Fiscal Studies.

Borensztein, E., De Gregorio, J., \& Lee, J.W. (1998). How does foreign direct investment affect economic growth? Journal of International Economics, 45, 115-135.

Bonds, S. (2002). Dynamic panel data models: A guide to micro data methods and practice. Portuguese Economic Journal, 1, 141-162.

Brock, W., \& Durlauf, S. (2001). Discrete choice with social interactions. Review of Economic Studies, 68, 235-260

Caselli, F., Esquivel, G., \& Lefort, F. (1996). Reopening the convergence debate: A new look at cross-country growth empirics. Journal of Economic Growth, 1, 363-389.

Chen, P., \& Gupta, R. (2006). An investigation of openness and economic growth using panel estimation. University of Pretoria, Working Paper 2006-22.

Demetriades, P., \& Law, S.H. (2006). Finance, institutions and economic development. International Journal of Finanace and Economics, 11, 1-16.

Devarajan, S., Swaroop, V., \& Zou, H. (1996).The Composition of public expenditure and economic growth. Journal of Monetary Economics, 37(2), 313-344.

Dogan, E., \& Tang, T.C. (2006). Government expenditure and national income: Causality tests for five South East Asian countries. International Business and Economics Research Journal, 5(10), 49-58.

Durlauf. S. (1990). Locally interacting systems, coordination failure, and the behaviour of aggregate activity. Working Paper, Stanford University.

Easterly, W., \& Levine, R. (1997). Africa's growth tragedy: Policies and ethnic divisions. Quarterly Journal of Economics, 112(4), 1203-1250.

Eller, M., Haiss, P., \& Steiner, K. (2006). Foreign direct investment in the financial sector and economic growth in Central and Eastern Europe: The crucial role of the efficiency channel. Emerging Market Review 7, 300-319.

Ellison, G. (1993). Learning, local interaction and coordination. Econometrica, 61, 1047-1072.

Gangopadhyay, S., \& Chatterji, A. (2005). Economic Globalisation in Asia, Aldershot, Hants, Ashgate Publishing. 
Gerson, P. (1998). The impact of fiscal policy variables on output growth. Working Paper 98/1, International Monetary Fund.

Ghura, D., \& Hadjimichael, M.T. (1996). Growth in Sub-Saharan African. IMF Staff Paper, 43, 605-635.

Goldsmith, A.A (1995). Democracy, property rights and economics growth. The Journal of Development Studies, 32 (2), 157-174.

Gwartney, J., Lawson, R., \& Block, W. (1996). Economic freedom of the world: 1975-1995. Vancouver: Fraser Institute.

Heller, P.S. (1997). Fiscal policy management in an open capital regime. Working Paper WP/97/20, Washington, DC,

Hoeffler A.K. (2002). The augmented Solow Model and the African growth debate. Oxford Bulletin of Economics and Statistics, 64(2), 0305-9049.

Holtz-Eakin, D., Newey, W., \& Rosen, H.S. (1988). Estimating vector autoregressions with panel data. Econometrica, 56, 1371-1395.

Hsiao, C. (1986). Analysis of panel data. Cambridge: Cambridge University Press.

Islam, N. (1995). Growth empirics: A panel data approach. Quarterly Journal of Economics, 110, 1127-1170.

Knack, S., \& Keefer, P. (1995). Institutions and economic performance: Cross-country tests using alternative institutional measures. Economic and Politics, 7(3), 207-227.

Knight, M., Loayza, N., \& Villanueva, D. (1993). Testing the neoclassical theory of economic growth, A panel data approach. International Monetary Fund Staff Paper, 40(3).

Law, S.H., \& Demetriades, P. (2006). Openness, institutions and financial development. World Economy \& Finance Research Programme. Working Paper Series WEF 0012.

Leblang, D.A. (1996). Property rights, democracy and economic growth. Political Research Quarterly 49(1), 5-26.

Levine, R., \& Renelt, D. (1992). A Sensitivity analysis of cross-country growth regressions. American Economic Review, 82, 942-963.

Lipset, S. M. (1959). Some social requisites of democracy: Economic development and political legitimacy. American Political Science Review, 53(1), 69-105.

Mankiw, G., Romer, D., \& Weil, D. (1992). A contribution to the empirics of economic growth. Quarterly Journal of Economics, 107, 407-437.

Nickell, S. (1981). Biases in dynamic models with fixed effects. Econometrica, 49, 1417-1426. 
North, D. (1990). Institutions, institutional change and economic perfromance. Cambridge: Cambridge University Press.

North, D.C., \& Thomas, R.P. (1973). The rise of the western world: A new economic history. Cambridge: Cambridge University Press.

Przeworski, A., \& Limongi, F. (1997). Modernisation theories and facts. World Politics, 49,155-183.

Rodrik, D. (1997). TFPG controversies, institutions, and economic performance in East Asia. National Bureau of Economic Research Working Paper 5914.

Rodrik, D., Subramaniam, A., \& Trebbi, F. (2002). Institution rule: The primacy of institutions over geography and intergration economic development, NBER Working Paper 9305.

Rosenberg, N., \& Birdzell, J.E. (1986). The economic transformation of the industrial world. New York: Basic Books.

Sala-i-Martin, X., \& Subramanian, A. (2003). Addressing the natural resource curse: An illustration from Nigeria, NBER Working Paper No. 9804. NBER, Cambridge, MA.

Tang, T.C. (2001). Testing the relationship between government expenditure and national income in Malaysia. ANALISIS, 8(1\&2), 37-51.

Tanzi, V., \& Zee, H. (1997). Fiscal policy and long-run growth. International Monetary Fund Staff Papers, 44, 65-94.

Zagler, M., \& Dürnecker, G. (2003). Fiscal policy and economic growth. Journal of Economic Survey, 17(3), 397-418.

212 IJMS 16 (1), 185-212 (2009) 